\title{
Greek inscriptions and documentary texts and the Graeco-Roman historical tradition
}

Book or Report Section

Published Version

Creative Commons: Attribution-Noncommercial-No Derivative Works 4.0

Open access

Mairs, R. ORCID: https://orcid.org/0000-0001-9192-9031 (2020) Greek inscriptions and documentary texts and the Graeco-Roman historical tradition. In: Mairs, R. ORCID: https://orcid.org/0000-0001-9192-9031 (ed.) The GraecoBactrian and Indo-Greek World. Taylor \& Francis, pp. 419-429. ISBN 9781315108513 doi:

https://doi.org/10.4324/9781315108513-21 Available at https://centaur.reading.ac.uk/102688/

It is advisable to refer to the publisher's version if you intend to cite from the work. See Guidance on citing.

To link to this article DOI: http://dx.doi.org/10.4324/9781315108513-21

Publisher: Taylor \& Francis

All outputs in CentAUR are protected by Intellectual Property Rights law, including copyright law. Copyright and IPR is retained by the creators or other copyright holders. Terms and conditions for use of this material are defined in the End User Agreement. 


\section{CentAUR}

Central Archive at the University of Reading

Reading's research outputs online 


\section{CHAPTER 17}

\section{GREEK INSCRIPTIONS AND DOCUMENTARY TEXTS AND THE GRAECO-ROMAN HISTORICAL TRADITION}

\section{Rachel Mairs}

\section{INTRODUCTION}

The nineteenth- and twentieth-century intellectual 'custody battles' over the GraecoBactrian and Indo-Greek kingdoms are the product of geopolitical forces but, on a more personal level, of individual scholarly training. As Svetlana Gorshenina and Claude Rapin have shown in their chapter in this volume, Russian imperial expansion into Central Asia and rivalry with Britain, and later Soviet ideological priorities, influenced how the culture and society of Hellenistic Central Asia was written about in Russia and the Soviet Union. In his contribution to this volume, Omar Coloru has similarly demonstrated how imperialism and political circumstances in Western Europe and South Asia also led scholars to write about the Graeco-Bactrian and Indo-Greek kingdoms in particular ways. Within these wider intellectual frameworks, scholars have also approached the topic with a narrower, more individual perspective: that of their own educational training. Until the archaeological discoveries of the mid-twentieth century, Central Asian antiquity was the field of the philologist and the numismatist. It remains a field in which collaboration between scholars of text and language and of material culture is essential, to make the most of a fragmentary historical and archaeological record. The first scholars to write about the Graeco-Bactrian and Indo-Greek states, in Europe in the eighteenth and nineteenth centuries, were educated according to the standard of the times, in Latin and Greek. A smaller number, particularly those who worked in Russia or South Asia, might have had some exposure to Chinese (Bayer in St Petersburg) or Indian languages (Prinsep in Calcutta). Given their grounding in Greek and Roman historical sources, it is unsurprising that European scholars tended to look at Central Asia through this lens: as a place at the fringes of the 'Classical' world, whose Hellenism (or otherwise) was the most important issue at stake. It was only later in the nineteenth and twentieth centuries that European scholars began to take account of South and East Asian textual traditions on Central Asia, and that scholars from these regions, with training in their own philological traditions, themselves entered the field.

The chapters in this section explore how three philological traditions - GraecoRoman, South Asian and Chinese - have been and can be used to contribute to our understanding of Central Asia in the Hellenistic period. It should be read as a 
complement to Section 3, on the archaeological record, and Section 5, on the numismatic record. In this chapter, I aim to outline the current state of the written evidence in Greek and Latin - including both texts from excavated contexts and those from the manuscript tradition - to explore how this evidence has traditionally been used to interpret the history and culture of Hellenistic Central Asia, and to offer some prospective avenues for future research.

\section{INSCRIPTIONS AND DOCUMENTARY TEXTS}

\section{Inscriptions}

Greek inscriptions and documentary texts from Central Asia are a relatively recent discovery. The first Greek inscription from Afghanistan was discovered only in the I950s (the Graeco-Aramaic Aśokan edict from Kandahar). The most recent discoveries are from the 20Ios, and there will almost certainly be more between the time this book goes to press and its publication.

The most convenient place to consult the Greek texts from Hellenistic Central Asia is in Rougemont's (20I2) volume in the series Corpus Inscriptionum Iranicarum. Rougemont's collection has the great advantage of including texts on ceramics and perishable materials as well as inscriptions on stone. Canali De Rossi's 2004 corpus, while also useful, does not contain several more recently-published items. Given ongoing excavations in the region, and the continuing emergence of pieces from the antiquities market (and often subsequent disappearance back into private collections), it will remain necessary to supplement these volumes with newer publications. In recent years, new finds have tended to be announced in the Zeitschrift für Papyrologie und Epigraphik (e.g. Tribulato and Olivieri 20I7; Clarysse and Thompson 2007) or Comptes-rendus des séances de l'Académie des Inscriptions et Belles-Lettres (e.g. Bernard and Rougemont 2003), and reported in the Hellenistic Far East Bibliography (www.bactria.org).

Stone inscriptions in Greek (or including Greek as one of their languages) come from a small number of sites: Kandahar, Djiga-tepe in the Bactra oasis, Ai Khanoum, Takht-i Sangin and Kuliab. The majority are religious and/or funerary in character, and most are very short or fragmentary. From Kandahar (Ball this volume) come three Aśokan texts, one of which is in Greek alone and another bilingual GreekAramaic (Rougemont 82-83), and the thanks-dedication of the 'Son of Aristonax' (Rougemont 8I). The inscription of Sōphytos son of Naratos probably also comes from Kandahar (Rougemont 84). The piece from Djiga-tepe (Martinez-Sève this volume) is a fragmentary funerary stele belonging to a man named Diogenes (Rougemont 9I). The Ai Khanoum (Martinez-Sève this volume) inscriptions are a portion of the Delphic maxims with an additional text describing Klearchos' bringing of them to the 'temenos of Kineas' (Rougemont 97); a gymnasial dedication to Hermes and Herakles by Straton and Triballos, sons of Straton (Rougemont 98); and two fragmentary funerary inscriptions (Rougemont 236 and 237). Takht-i Sangin (Lindström this volume) yielded a small plinth with a dedication by Atrosokes to the god Oxos (Rougemont 95). Although not inscriptions per se, it is also appropriate to consider alongside the Takht-i Sangin dedication moulds from the temple, designed for the casting of metal vessels and containing votive Greek inscriptions to 
the Oxus (Rougemont 96 bis; Drujinina 2008; Ivantchik 20I I). An altar dedicated by Heliodotos to Hestia in a 'grove of Zeus' on behalf of the kings Euthydemos and Demetrios is said to have come from Kuliab (Rougemont I5 I; cf. Lindström this volume). The publication of a Greek inscription from historic excavations at a temple site at Sehyak in Afghan Seistan is under preparation by Mitchell Allen, Lauren Morris and the present author. It contains, unfortunately, only sufficient preserved text to identify the language as Greek, not to gain much insight into its original contents.

\section{Epigraphic traditions}

The first publications of Greek inscriptions from Afghanistan immediately confronted scholars with the same questions of scholarly 'custody' as the numismatic, historical and archaeological material. Did these inscriptions support the argument that Central Asia was part of a 'Greek' world (Tarn's “fifth Hellenistic state”: Coloru this volume)? The first Greek inscription discovered in the region, the bilingual GreekAramaic Aśokan edict could, from a Classical point of view, be seen as paradoxical: the use of a Greek inscription and the Greek language to express the political and ethical will of an Indian king. The inscription was also bilingual in Aramaic. Giuseppe Tucci, in his introduction to the full publication of the bilingual inscription, was of the view that "no doubt the inscription, that implicitly confirms the importance of the Greek element in that part of the Asian world, is bound to give rise to additional controversy. ... This inscription proves once more how very close to us are the countries of Asia, how closely bound to our own history, through remote but uninterrupted events" (Tucci in Pugliese Carratelli and Garbini I964, xi). Although subsequent epigraphic discoveries at Kandahar made the complex linguistic, cultural and political landscape of the region clear - the monolingual Greek Aśokan edict contains Prākrit loanwords, and one of the Aśokan texts is in a form of Prākrit written in Aramaic script - the scholarly focus has drifted towards a Greek epigraphic perspective, away from one which privileges the hybrid, multilingual nature of these texts. Recent studies of multilingual inscriptions from elsewhere in the Hellenistic world have given equal attention to the individual languages of the text, and to their interrelationship (e.g. Pfeiffer 2004; El-Masry, et al. 20I2). It is to be hoped that studies of the Aśokan texts from Kandahar and the Laghman valley will move in a similar direction (Mairs forthcoming-b). Beyond the epigraphic corpus of Central Asia, there is also considerable scope in comparative studies (see Mairs 20I4b, IO2-I45) for a comparative treatment of the Greek inscription of Sōphytos from Kandahar and the Prākrit inscription of Heliodoros from Besnagar in central India).

The reason why the dominent narrative has been that of the 'Greek' nature of the epigraphic record from Central Asia is twofold. First, discoveries subsequent to the Aśokan edicts have been monolingual in Greek, and direct references within the text relatively monocultural. Second, scholars with the specialist skillset to work with Greek inscriptions tend to be less at home with material in Aramaic or Prākrit, and vice versa. Greek inscriptions have formed an important part of the evolving scholarly narrative about Ai Khanoum and its cultural identity (Martinez-Sève, this volume). For scholars of the I960s, their very presence lent weight to the status of the city as an important 'Greek' establishment, and moreover as a worthy object of 
study. Louis Robert, discussing W. W. Tarn's pessimistic hopes for the discovery of an 'Iranian Doura Europos', noted the centrality of the written text to Tarn's notion of 'Hellenistic civilisation': "la fouille d'un site grec «avec des inscriptions". Celles-ci sont en effet des documents privilégiés et irremplaçables pour l'intelligence historique" (Robert I968, 4I7). The content of the Greek inscriptions from Central Asia also lent itself to a focus on the 'Greek'. Louis' Robert's classic study 'De Delphes à l'Oxus', from which I have just quoted, devotes considerable space to discussing the evidence for philosophical and cultural connections between the Mediterranean world and South and Central Asia, but it also highlights the quintessentially, blatantly Greek cultural priorities of the Ai Khanoum inscriptions from the gymnasium and the temenos of Kineas. What the stereotypically - almost clichéd - 'Greek' references to Hermes, Herakles and Delphi amount to in terms of the cultural identities of the city's inhabitants is a matter of considerable debate (Mairs 20I4b, I79- I 84).

Comparison with other regions of the Classical world, broadly defined, can be instructive. Can these scattered inscriptions be said to amount to a Greek 'epigraphic habit' in Central Asia? Certainly, they constitute a fairly representative sample of the kinds of contexts which called for inscriptions elsewhere in the Hellenistic world: personal dedications to gods at religious sites; tombs or cemeteries; and even public statements of private individuals' loyalty to kings, and kings' enforcement of their own authority. On the other hand, although it is difficult to speak for the region as a whole, the thorough exploration of a site such as Ai Khanoum indicates that Greek public inscriptions were not as prominent a feature of the urban and civic landscape as they were in many other Hellenistic cities. There are many possible reasons for this, both cultural/linguistic (fewer people who could read a Greek inscription?) and practical (less extensive use of stone as a building material). As well as the Hellenistic world, the impetus to set up public inscriptions in Central Asia came also from Achaemenid and Mauryan precedent. The Aśokan Edicts at Kandahar, in particular, show interactions between the epigraphic culture of the Mediterranean and that of South Asia, where a stone inscription was considered an appropriate - and presumably efficacious - way to make a public statement of a king's military power and ethical instructions to his subjects.

\section{Administrative documents}

By far the best documented Hellenistic bureaucracy is that of Ptolemaic Egypt, where conditions of preservation allow the operations of a vast, multilingual administration to be reconstructed to a degree impossible elsewhere in the ancient world. The same climatic conditions do not prevail in Central Asia and North-West India. As in Egypt, we know that papyrus was used from the imprint of the piece from the Ai Khanoum Treasury, but we do not know to what extent, and - if it was - no more has been preserved. Animal skin was used for the few surviving documents. This may well have been the dominant writing material, in fitting with the pastoral economy of Central Asia.

The administration of Achaemenid-period Bactria (see Wu this volume) is considerably better attested than that of the Hellenistic period, but still only by a single archive of Aramaic texts, published by Naveh and Shaked (Naveh and Shaked 20I 2; an earlier announcement: Shaked 2004). These most probably came from the central 
satrapal archive at Bactra, and many of them concerned correspondence between the satrap, Akhvamazda, and his subordinate, Bagavant, at Khulmi (on Khulmi see Martinez-Sève this volume). The Aramaic documents come down to the years immediately after the conquest by Alexander (document $\mathrm{C}_{4}$ is dated to Year 7 of Alexander) - indicating some continuity of adminstration, however brief - but there is then a considerable documentary gap before the first Greek documents, which are very different in nature. We cannot therefore say to what extent the Greek administration built upon and continued the Achaemenid one, although my own inclination is towards a considerable degree of administrative continuity (Mairs 20I 4 b, 43-46).

We can divide the Greek administrative or official documents from Bactria into two groups: ink texts on ceramic vessels from Ai Khanoum (Rougemont 90-I20) and a few pieces on skin (Rougemont 92, 93), none of which are securely provenanced.

The Ai Khanoum texts relate to activities in the treasury of the palace (Rapin I983). Commodities and quantities of coin (both Greek and Indian) are mentioned, as are the names of the officials involved, which are both Greek and Iranian (Grenet I983). The texts are brief and to the point, and fairly formulaic. The texts on skin are a tax receipt dated to a joint reign of Antimachos, Eumenes and Antimachos, written in a place named Asangorna and containing the names of several officials (Rougemont 92); and a possible contract of Year 30 of an Antimachos, written in Amphipolis and mentioning Scythians (Rougemont 93). A second text published in Clarysse and Thompson 2007, but not included by Rougemont, is too badly damaged to yield a secure reading, although it appears to mention phorai 'transport'.

It is not possible to match any of the personal or place names in these texts with people or locations attested elsewhere. The exception, of course, are the royal names, but here too the documents bring information not otherwise known: a co-regency of Antimachos, Eumenes and a second Antimachos was not otherwise attested. More than political history, however, the documentary texts are testimony to the existence of a state bureaucracy and the use of writing and institutions by individuals to manage their affairs.

\section{Other texts}

While most of the Greek writings from Central Asia fall into these two categories stone inscriptions and administrative documents - there are others. At one extreme, we find two literary texts from the Ai Khanoum treasury: a fragment of a dramatic work on parchment (Rougemont I32) and the impression of a papyrus containing a philosophical dialogue (Rougemont I33). At the other extreme, are much shorter texts, usually on potsherds or bricks, containing only a name or a letter or two, from a wide range of sites across Graeco-Bactrian and Indo-Greek territory, from Samarkand to Barikot. These represent the two extremes of Greek literacy in the Graeco-Bactrian and Indo-Greek states. On the one hand, there were people capable of reading and writing 'high' literature. Some of the inscriptions from the region also indicate that their writers had an advanced education. The Sōphytos inscription and the Aśokan edicts, in particular, use sophisticated, arcane vocabulary, something which was a feature of the literary production of the wider Hellenistic world. On the other hand, stray Greek letters used as brick marks (for example at Samarkand) do not have to involve any literacy at all, still less knowledge of the Greek language. 


\section{How closely connected was Central Asia to the Hellenistic world?}

As well as their use of the Greek language, and occasional choice of recherché Hellenistic literary vocabulary, texts from Central Asia provide additional evidence for the integration of the region into wider Achaemenid, and later Hellenistic, networks. Robert's seminal 'De Delphes à l'Oxus' (discussed above) set the agenda by examining how the inscription of Klearchos from the temenos of Kineas at $\mathrm{Ai}$ Khanoum deliberately sets out to forge a direct connection between the banks of the Oxus and the symbolic centre of the Greek world.Robert proposed that Klearchos himself should be identified with the philosopher Klearchos of Soloi. Klearchos' inscription, and the placement of the shrine of Kineas in the centre of the city, also share practices in common with foundations of settler colonies elsewhere in the Greek world (Mairs 20I4a). Other inscriptions also make outright declarations of their attachment to Greek culture. Sōphytos is the most overt, in his invocation of Apollo and the Muses, and emphasis on his education.

There are more subtle, but still visually arresting, ways in which texts show connections to wider worlds. The palaeography and formulae of Aramaic and Greek documentary texts from Bactria are very similar to those of contemporary Egypt, the region of the ancient world with the best documentary record, and which was, like Bactria, also part of the Achaemenid and Hellenistic empires. Folmer compares the Arsames correspondence (from Egypt, but written in Babylon or Susa) with the Bactrian corpus and concludes that the many similarities "contribute to the image of a well-organized system of chancelleries working to produce official documents in a uniform way across the empire. This amounts to an astonishing achievement considering the spatial and temporal distances between the material in question" (Folmer 20I7, 442). This evidence of widely-spread networks of scribal training and practice continues into the Hellenistic period. Rea says of the Greek tax receipt that "I would not have been able to tell from the writing alone that it did not come from Egypt" (Rea, et al. I994, 262). In their publication of the other two Greek documents on skin, Clarysse and Thompson also point out the close adherence of Greek documentary hands and epigraphic letter forms to examples from elsewhere in the Hellenistic world, but also urge caution in using these as dating criteria (Clarysse and Thompson 2007). Just as the material culture of Central Asia demonstrates long distance connections and integration into pan-Eurasian networks of trade and imperial control, so too does the written record.

\section{How widely was the Greek language used?}

The presence of Greek inscriptions and administrative documents obviously cannot be taken as a proxy for the use of Greek as a spoken language of communication. In Central Asia at least, for most of the period with which we are concerned, Greek was the only available language of literacy. This means that it took on functions regardless of its status or otherwise as a widespread spoken language. In the Achaemenid period, Aramaic held this same position. The situation south and east of the Hindu Kush was somewhat different, with the Brāhmī and Kharoșthī scripts already in use (see Jansari this volume). We should be especially cautious in taking isolated Greek letters as evidence of presence of the Greek language. As has been shown for more 
recent colonial contexts, foreign scripts introduced by settlers or colonisers can be received and take on their own meanings by indigenous populations (e.g. van Toorn 2006 on Australia). The culmination of this in Central Asia is the adaptation of the Greek script to write the Bactrian language under the Kushans (Cribb this volume).

Although it may be supposed, from the later evidence of the Bactrian and Gāndhārī languages, that multiple Middle Indo-Iranian languages were spoken across the region, we have very little evidence of these, aside from onomastics. The only Greek texts in which we can see indisputable linguistic interference are the Aśokan edicts from Kandahar and, as translations or reworkings of Prākrit originals, these have a special status. Iranian names in Greek texts include Atrosokes at Takht-i Sangin and the names of Sōphytos and his father Naratos at Kandahar have been identified as Indian (Pinault 2005). In Bactria, theophoric Oxus-names are especially prevalent, such as Oxēboakēs in the Ai Khanoum economic texts. These are the tip of the linguistic iceberg: hints at a much more complex landscape of languages and cultural traditions in Central Asia.

\section{THE GREEK AND ROMAN TRADITION}

There is no surviving Greek or Latin historical work which deals with the GraecoBactrian and Indo-Greek kingdoms at any length: a source of immense frustration to the first European historians of the region (Coloru this volume). For the Mediterranean world, scholars had long been used to being able to draw on the works of Greek and Roman historians who wrote both detailed studies of individual periods or events (such as Julius Caesar's Gallic War or Thucydides' History of the Peloponnesian War) or more comprehensive histories, often seen from the perspective of a particular state (for example, Livy's History of Rome). When these same scholars came to write on Hellenistic Central Asia, the relative lack of Greek and Roman historical sources was seen as a serious detriment, a major impediment to 'writing history' of Central Asia. Modern historians writing from this perspective, whether Bayer or Tarn, have therefore seen their goal as one of historical reconstruction: recreating a lost narrative. This led many of them into creative (to use a euphemism) reconstructions of Central Asian dynasties based on the numismatic record (Glenn this volume, and Section 5). Rather than a deficiency in a lost historical record (which may never have existed) it is more productive to take the few Greek and Roman historical writings we do have on Central Asia as an opportunity. How can the evidence transmitted by these authors - but, more importantly, how they contextualise this 'information' and where they derive it from - supplement and complement the evidence from material culture and epigraphic and documentary sources?

Most of the relevant passages from Greek and Roman writers on the GraecoBactrian and Indo-Greek kingdoms are conveniently collected in English translation in the appendices to Holt's Thundering Zeus. They occupy less than six pages (Holt I999, I78-I 84). Even collections with a broader remit, such as McCrindle's compendia of Greek and Roman sources on India (e.g. McCrindle I926; discussed by Mairs 20I 8), are able to fit the entirety of the 'Classical tradition' on their topic into a single volume. The majority of Graeco-Roman sources which do touch upon the region are written by authors who had no first-hand familiarity with it and - especially in the Roman period - had cultural expectations which led them to stereotype 
Central Asia and India as lands of mythical creatures and barbarian customs. They must be read with this in mind. I provide here a brief resume of the most important Greek and Roman historical sources, and shall return below to consider how these might most productively be used.

\section{Contemporary accounts}

No contemporary account of Alexander's campaigns survives, although we know that a number were written, including by Ptolemy and Nearchos. Alexander historians such as Arrian, Quintus Curtius Rufus and Plutarch, do not deal with the subsequent history of Hellenistic Central Asia, but do contain potentially valuable information on historical geography and city foundations. They are discussed in several of the contributions to the present volume for that reason, but I shall not review them further here.

There are also no surviving contemporary accounts on the early Seleukid East, or the Graeco-Bactrian and Indo-Greek kingdoms themselves, although again we know that these did once exist. Perhaps the most tantalising is the work of Megasthenes, a Seleukid ambassador to the Mauryan court (see Jansari this volume, and on Greek sources on India and the Mauryas more generally, Karttunen I989). It is not known whether any inhabitant of the Graeco-Bactrian or Indo-Greek states ever wrote a history of their own. Given the evidence for the composition of scholarly works in Greek at Ai Khanoum (see above) it is possible that they did.

\section{Polybios}

Polybios' Histories cover the period 264-46 BC and were written in Greek in the mid-second century BC; the work does not survive in its entirety. He is one of the most useful historians for the Hellenistic world as a whole, but provides little information on Central Asia and India. Bactria is prominent only when it is of relevance to the Seleukids, notably in the eastern anabasis of Antiochos III. Polybios describes Antiochos' invasion of Bactria (I0.49) and the seige of Bactra (II.34), including negotiations with Euthydemos and his son Demetrios. Volume II of Walbank's Historical Commentary on Polybius includes these episodes (Walbank I967).

\section{Strabo}

In his Geography, written in Greek in the early first century AD (translation with notes: Roller 20I4; historical and topographical commentary: Roller 20I8), Strabo mentions several political events in passing: the Graeco-Bactrian revolt from the Seleukid empire (I 5.I.3); Euthydemos' 'rebellion' against the Seleukids (I I.9.2) and the Graeco-Bactrian expansion into India under Demetrios son of Euthydemos and Menander (II.II.I). He also names Diodotos (II.9.3) and Eukratides (II.II.2). The Graeco-Bactrian and Indo-Greek kingdoms are, however, never his main focus. $\mathrm{He}$ is more interested in the rise of the Parthian Empire, describing the lie of the land in Central Asia, or transmitting ethnographic factoids likely to scandalise a Greek readership (for example, the supposed Bactrian habit of throwing their dead to dogs: I I.I I.3; cf. Plutarch Moralia 499 D). 


\section{Justin and Pompeius Trogus}

Trogus, a Gallo-Roman, wrote his Philippic Histories - a 'universal history' - in Latin in the first century BC. The work is lost, but was summarised in Latin by Justin in the second century AD (translation and commentary: Yardley and Develin I994). Chapter 4I of Justin's Epitome deals with the Graeco-Bactrian kingdoms, but only very briefly; like Strabo, he is more concerned with Parthia and the Seleukid Empire. Justin mentions that Diodotos (whom he calls Theodotus) rose to power at around the same time as Arsakes in Parthia (4I.4). He identifies a second synchronism in the rise to power of Mithradates of Parthia and Eukratides of Bactria, and says that Eukratides was beset by conflicts with neighbouring states and later murdered by his own son (4I.6).

\section{The Periplus of the Erythraean Sea}

This Greek mariner's manual, by an unknown author, was most probably written in the first century $\mathrm{AD}$ (Casson I989). It is a practical guide to contemporary routes, ports and trade goods along the route from the Red Sea coast of Egypt, southern Arabia and the Horn of Africa to southern India. At the time it was written, the Graeco-Bactrian and Indo-Greek kingdoms had already disappeared, but it records that memory of them was still current. At Barygaza, in modern Gujarat, it states (47) that drachms of Apollodotos and Menander could still be found, and the author was aware that these were kings of the period after Alexander.

\section{Using these sources}

It is not possible to use these sources to reconstruct a coherent political history of the Graeco-Bactrian and Indo-Greek states, certainly not in the style one might of other, better-documented regions of the Hellenistic world. Attempts have, of course, been made, as I noted above. Tarn set out to reconstruct the general outlines of the hypothetical lost work written by "Trogus' source" (Tarn I95 I [I938], 45- 53). Combinations of the Greek and Roman sources with numismatic evidence tend to produce narratives which are more construction than reconstruction (e.g. Rawlinson I 909). If we abandon the project of composing a narrative political history, then the prospects for making productive use of these sources are rather better. Topographical information can, for example, be used to propose identifications of excavated sites (on possible locations of Eukratideia, see Lecuyot, Martinez-Sève and Stančo, this volume). It is, of course, necessary to exercise caution in this exercise, just as it is (for example) important not to rush to ascribe destruction levels at archaeological sites to individual military campaigns mentioned by Greek and Roman historians. Justin's synchronisms - if these are accurate - can be used to provide chronological anchors, and play a role in determining the dates of the reigns of kings known only from the numismatic record (Mairs forthcoming-a). Polybios' account of the seige of Bactra can suggest how Graeco-Bactrian kings presented themselves to other Hellenistic monarchs. Most poignantly, the scarce mentions of Central Asia and India in surviving Greek and Roman accounts are some indication of how little they impinged upon the consciousness of the world to the west, whatever their own views may have been of their position in that world. 


\section{REFERENCES}

Bernard, Paul and Georges Rougemont (2003) "Une nouvelle inscription grecque de l'Afghanistan," Comptes-rendus des séances de l'Académie des Inscriptions et BellesLettres I I 59-II6I.

Canali De Rossi, Filippo (2004) Iscrizioni dello Estremo Oriente Greco: Un Repertorio. (Inschriften Griechischer Städte aus Kleinasien 65.) Bonn: Dr. Rudolf Habelt.

Casson, Lionel (1989) The Periplus Maris Erythraei. Princeton: Princeton University Press.

Clarysse, Willy and Dorothy J. Thompson (2007) "Two Greek Texts on Skin from Hellenistic Bactria," Zeitschrift für Papyrologie und Epigraphik I 59, 273-279.

Drujinina, Anjelina (2008) "Gussform mit griechischer Inschrift aus dem Oxos-Tempel," Archäologische Mitteilungen aus Iran und Turan 40, I2 I-I35.

El-Masry, Yahya, Hartwig Altenmüller and Heinz-Josef Thissen (2012) Das Synodaldekret von Alexandria aus dem Jahre $243 v$. Chr. Hamburg: Helmut Buske Verlag.

Folmer, M. L. (2017) "Bactria and Egypt. Administration as Mirrored by the Aramaic Sources," in B. Jacobs, W. F. M. Henkelman and M. W. Stolper (eds.), Die Verwaltung im Achämenidenreich - Imperiale Muster und Strukturen, 4I3-454. Wiesbaden: Harrassowitz.

Grenet, Frantz (1983) “L'onomastique iranienne à Aï Khanoum,” Bulletin de Correspondance Hellénique 107, 373-38I.

Holt, Frank L. (I999) Thundering Zeus: The Making of Hellenistic Bactria. (Hellenistic Culture and Society XXXII.) Berkeley: University of California Press.

Ivantchik, Askold I. (20II) “Новые греческие надписи из Тахти-Сангина и проблема возникновения бактрийской письменности,” Vestnik Drevnei Istorii 279, I I -1 3 I.

Karttunen, K. (1989) India in Early Greek Literature. (Studia Orientalia 65.) Helsinki: Finnish Oriental Society.

Mairs, Rachel (20I4a) “The Founder Shrine and the 'Foundation' of Ai Khanoum,” in Naoíse Mac Sweeney (eds.), Foundation Myths in Dialogue: Discourses about Origins in Ancient Societies, I03-I28. Philadelphia: University of Pennsylvania Press.

Mairs, Rachel (20I4b) The Hellenistic Far East: Archaeology, Language and Identity in Greek Central Asia. Berkeley: University of California Press.

Mairs, Rachel (2018) "The Men Who Would Be Alexander: Alexander the Great and his Graeco-Bactrian Successors in the Raj," in Kenneth Moore (eds.), Brill's Companion to the Reception of Alexander the Great, 545-563. Leiden: Brill.

Mairs, Rachel (forthcoming-a) "Central Asian Challenges to Seleucid Authority: Synchronism, Correlation and Causation," in Paul J. Kosmin and Ian S. Moyer (eds.), Cultures of Resistance in the Hellenistic East. Oxford: Oxford University Press.

Mairs, Rachel (forthcoming-b) "Lexical Borrowing and Code-Switching in Translated Texts: The Case of Trilingual Inscriptions,” in Tor Ivar Østmoe and Anastasia Maravela (eds.), Translation in Antiquity; Translating Antiquity.

McCrindle, J. W. (I926) Ancient India as Described by Megasthenês and Arrian. Calcutta: Thacker, Spink \& Co.

Naveh, Joseph and Shaul Shaked (2012) Aramaic Documents from Ancient Bactria (Fourth Century B.C.E.) from the Khalili Collections. (Studies in the Khalili Collection.) London: The Khalili Family Trust.

Pfeiffer, Stefan (2004) Das Dekret von Kanopos (238 v. Chr.): Kommentar und historische Auswertung eines dreisprachigen Synodaldekretes der ägyptischen Priester zu Ehren Ptolemaios' III. und seiner Familie. (Archiv für Papyrusforschung und verwandte Gebiete. Beiheft I 8.) München: K. G. Saur.

Pinault, Georges-Jean (2005) "Remarques sur les noms propres d'origine indienne dans la stèle de Sôphytos," in Osmund Bopearachchi and Marie-Françoise Boussac (eds.), Afghanistan: 
Ancien carrefour entre l'est et l'ouest, I37-I42. (Indicopleustoi: Archaeologies of the Indian Ocean 3.) Turnhout: Brepols.

Pugliese Carratelli, Giovanni and Giovanni Garbini (1964) A Bilingual Graeco-Aramaic Edict by Asoka. The First Greek Inscription Discovered in Afghanistan. (Serie Orientale Roma 29.) Rome: Istituto italiano per il medio ed estremo Oriente.

Rapin, Claude (I983) "Les inscriptions économiques de la trésorerie hellénistique d'Aï Khanoum (Afghanistan)," Bulletin de Correspondance Hellénique I07, 3 I 5-38 I.

Rawlinson, H. G. (I909) Bactria: From the Earliest Times to the Extinction of Bactrio-Greek Rule in the Punjab (being the Hare University Prize Essay, I908). Bombay: The 'Times of India' Office.

Rea, John, R. C. Senior and Adrian S. Hollis (1994) “A Tax Receipt from Hellenistic Bactria," Zeitschrift für Papyrologie und Epigraphik 104, 26I-280.

Robert, Louis (I968) "De Delphes à l'Oxus: Inscriptions grecques nouvelles de la Bactriane," Comptes-rendus de l'Académie des inscriptions et belles-lettres 4I6-457.

Roller, Duane W. (2018) A Historical and Topographical Guide to the Geography of Strabo. Cambridge: Cambridge University Press.

Roller, Duane W. eds. (2014) The Geography of Strabo. Cambridge: Cambridge University Press.

Rougemont, Georges (20I2) Inscriptions grecques d'Iran et d'Asie centrale. (Corpus Inscriptionum Iranicarum II: Inscriptions of the Seleucid and Parthian Periods and of Eastern Iran and Central Asia. Vol. I Inscriptions in Non-Iranian Languages.) London: School of Oriental and African Studies.

Shaked, Shaul (2004) Le satrape de Bactriane et son gouverneur: Documents araméens du IVe s. avant notre ère provenant de Bactriane. (Persika 4.) Paris: de Boccard.

Tarn, W. W. (I95 I [1938]) The Greeks in Bactria and India. Cambridge: Cambridge University Press.

Tribulato, Olga and Luca Maria Olivieri (2017) "Writing Greek in the Swat Region: A New Graffito from Barikot (Pakistan)," Zeitschrift für Papyrologie und Epigraphik 204, I $28-\mathrm{I} 35$.

van Toorn, Penny (2006) Writing Never Arrives Naked: Early Aboriginal Cultures of Writing in Australia. Canberra: Aboriginal Studies Press.

Walbank, F. W. (1967) A Historical Commentary on Polybius. Vol. II: Commentary on Books VII-XVIII. Oxford: Clarendon Press.

Yardley, J. C. and R. Develin, eds. (1994) Justin: Epitome of the Philippic History of Pompeius Trogus. (Classical Resources Series 3.) Atlanta: Scholars Press. 